\title{
Relationships of New World Phlebotomine Sand Flies (Diptera: Psychodidae) Based on Fossil Evidence
}

\author{
José Dilermando Andrade Filho, Reginaldo Peçanha Brazil ${ }^{+}$
}

\author{
Laboratório de Leishmanioses, Centro de Pesquisas René Rachou-Fiocruz, Av. Augusto de Lima 1715, 30190-002 \\ Belo Horizonte, MG, Brasil
}

The fossil record and systematics of phlebotomid sand flies, vectors of leishmaniasis and arbovirus in several regions of the world, strongly support that living genera existed long before the Oligocene (38 million years, myr). A common Phlebotominae ancestor was present in the Triassic period before the separations of continents (248 myr).

Key words: Diptera - fossil Phlebotominae - sand flies - evolution

The arthropods first arose during the Pre-Cambrian period, about 550 million years (myr) ago. The first Parainsecta appeared in the Devonian (408 myr) and the insects in the Carboniferous (360 myr), when radiation of the earliest orders occurred. Diversification continued to occur in the following period, the Permian (286 myr), during which the Diptera arose. During the Triassic (248 myr) the gigantic continental mass known as Pangaea began to break up into the continents, a process which extended into the Jurassic (213 myr). Modern ecosystems arose at the end of the Triassic. By the Cretaceous most of the continents were already separated and there was considerable diversification among the angiosperms. This coincided with a pronounced increase in diversity of insect groups, particularly those associated with these plants, including the Diptera (Table).

The Psychodidae are now widespread on all continents except Antarctica, suggesting that the family has a long evolutionary history which began during the Mesozoic (Ansorge 1994). The earliest known psychodid is from the late Triassic of Virginia, USA (Fraser et al. 1996) and the next oldest specimens in this group is from the Jurassic period of Germany (Ansorge 1994). Large numbers of psychodids have been found preserved in amber from the Baltic region, Lebanon, Mexico and Burma (Myanmar) (Haenni 2001, Azar et al. 1999, Rasnitsyn \& Ross 2000, Morales \& Pimentel 2001).

There are a few records of Phlebotominae from Mexican, Lebanese and Baltic amber. The oldest sand flies have been found in Lower Cretaceous (120-135 myr) amber from Lebanon, at least four genera being recognised, i.e., Phlebotomiella Phlebotomites, Mesophlebotomites and Libanophlebotomus but they are no longer living genera. Phlebotomiella tipuliformis was described by Meunier, in 1905, from Baltic amber, in the genus Phlebotomus but was later modified by the same author (Meunier 1906).

This work was supported by $\mathrm{CNPq}$ and Fiocruz.

${ }^{+}$Corresponding author. Fax: +55-31-3295.3115. E.mail: rpbrazil@cpqrr.fiocruz.br

Received 26 August 2002

Accepted 25 November 2002
Both Phlebotomites brevifilis and P. longifilis were described by Hennig, in 1972, and more recently M. hennigi and L. lutfallahi by Azar et al. (1999) from the Lower Cretaceous Lebanon. There are one record of ancestral members of the living genus Phlebotomus, P. pungens (Loew, 1845) probably from the Holocene and Sergentomyia from the Eocene (Stuckenberg 1975) .

With respect to the New World, Quate (1963) described Micropygomyia paterna (= Lutzomyia paterna) from the Oligocene/Miocene. Until recently no formal species descriptions had been made of sand flies observed in amber from Hispaniola Island (Young \& Lawyer 1987). We recently described Pintomyia falcaorum, the second neotropical sand fly to be discovered in Miocene amber from the Dominican Republic (Brazil \& Andrade Filho 2002). A few more specimens in Dominican amber from the collection of one of the authors (RPB) are known to belong to the genera Micropygomyia and Trichopygomyia and need to be fully described. All the three genera are recognized in living species with distribution from North to South America. The genus Eophlebotomus Cockerell from Burmese Eocene amber was considered by Fairchild (1951) to be an intermediate form between the subfamilies Phlebotominae and Trichomyiinae or Sycoracinae. Duckhouse (2000) suggested that this genus could represent a common ancestor of the latter two subfamilies.

The genera Phlebotomites, Mesophlebotomites, Libanophlebotomus and Phlebotomiella may be placed in the tribe Hertigiini, subtribe Hertigiina Fairchild which presents more primitive characteristics than the tribe Phlebotomini, to which the present-day genera Pintomyia Costa Lima (subtribe Lutzomyiina Abonnenc \& Leger) and Micropygomyia Barretto (subtribe Sergentomyiina Artemiev) belong (Galati 1995). We believe that the great majority of the present genera already existed in the Oligocene period, including Lutzomyia França in the New World, Sergentomyia França \& Parrot and Phlebotomus Rondani in the Old World.

Most researchers accept that the family Psychodidae consists of the subfamilies Bruchomyiinae, Trichomyiinae, Psychodinae and Phlebotominae, as proposed by Hennig (1972). Since then several phylogenetic analyses have been made of the Psychodidae (Duckhouse 1972, Abonnec \& Leger 1976, Lewis et al. 1977, Williams 1993). According to recent studies by Galati (1995) the subfam- 
TABLE

Relationship of the earliest phlebotmines in the different geological epochs. Table based on dates estimated by Harland et al. (1982)

\begin{tabular}{|c|c|c|c|}
\hline Periods & Epochs & Principal events & Region \\
\hline Quaternary (11000-2,5 myr) & $\begin{array}{l}\text { Holocene (Recent) }(11,000) \\
\text { Pleistocene }(2.5 \mathrm{myr})\end{array}$ & $\begin{array}{l}\text { Glaciations } \\
\text { Glaciations }\end{array}$ & \\
\hline Tertiary $(5,1-65$ myr $)$ & $\begin{array}{l}\text { Pliocene (5.1 myr) } \\
\text { Miocene ( } 24.6 \mathrm{myr}) \\
\text { Oligocene (38 myr) } \\
\text { Eoceno (54.9 myr) } \\
\text { Palaeocene ( } 65 \mathrm{myr})\end{array}$ & $\begin{array}{l}\text { Isthmus of Panamá } \\
\text { Pintomyia/Micropygomyia/Trichopygomyia } \\
\text { Present genera of Phlebotominae } \\
\text { Micropygomyia } \\
\text { Phlebotomiella/Sergentomyia }\end{array}$ & $\begin{array}{l}\text { Caribbean } \\
\text { Mexico } \\
\text { Baltic }\end{array}$ \\
\hline Cretaceous (144 myr) & & $\begin{array}{l}\text { Most continents widely separated } \\
\text { Bering straits formed } \\
\text { Phlebotomites, Mesophlebotomites, } \\
\text { Libanophlebotomus }\end{array}$ & \\
\hline Jurassic (213 myr) & & $\begin{array}{l}\text { Separation of Continents } \\
\text { Differentiation of tribes Hertigiini and } \\
\text { Phlebotomini }\end{array}$ & \\
\hline Triassic (248 myr) & & $\begin{array}{l}\text { Beginning of separation of continents } \\
\text { Ancestors of Phlebotominae } \\
\text { Earliest psychodids }\end{array}$ & North America \\
\hline Permian (286 myr) & & $\begin{array}{l}\text { Continents joined } \\
\text { Earliest Diptera }\end{array}$ & \\
\hline Carboniferous (360 myr) & & Earliest orders of the Insecta & \\
\hline Devonian (408 myr) & & Parainsecta & \\
\hline \multicolumn{4}{|l|}{ Silurian (438 myr) } \\
\hline \multicolumn{4}{|l|}{ Ordovician (505 myr) } \\
\hline Cambrian (570 myr) & & Arthropoda & \\
\hline \multicolumn{4}{|l|}{ Vendian (670 myr) } \\
\hline Sturtian (800 myr) & & & \\
\hline
\end{tabular}

ily Phlebotominae Rondani may be divided into two tribes: Hertigiini Abonnenc \& Leger and Phlebotomini Rondani. The Hertigiini present various plesiomorphies in relation to members of their sister group in the subfamily Bruchomyiinae Alexander and incorporate the neotropical sand fly genera Warileya Hertig and Hertigia Fairchild. The Phlebotomini Rondani present the greatest number of apomorphies and this tribe includes most of the neotropical species.

It is known that the flight capacity of phlebotomines is very limited (Chaniotis \& Coura 1974, Morrison 1993) as is their vagility, i.e., the geographical distance between where a zygote is formed and where the resulting insect will be born. One would therefore expect most species to be limited to certain well-established and delimited geographical areas, as result of small gene flow between the populations and consequently little phenotypic variation in the species. However this is not what is observed. Species such as L. longipalpis (Lutz \& Neiva), Psathyromyia shannoni (Dyar) and Phlebotomus papatasi (Scopoli) present wide geographical distributions leading to the formation of clines or even taxonomically confusing in- traspecific variations, it being difficult to know to whether or not these maintain reproductive isolation.

The subfamily Phlebotominae is distributed over all the zoogeographical regions. This may be explained by vicariance events, i.e., the discontinuous distribution of closely related groups (Amorim 1994). Based on fossil evidence Kerr (2000) and Kerr et al. (2000) suggest that the ancestor of Sergentomyia and Phlebotomus evolved in the Palearctic region during the Cretaceous, whereas for Noyes et al. (2000) these genera arose when Pangaea was still intact, before the separation of the continents. According to Lewis (1982) the ancestor of the phlebotomines arose in the Cretaceous. However we think that they arose around the Triassic period, about 248 myr ago, before the breakup of Pangaea and subsequently began to disperse to each continent, giving rise to the wide variety of modern genera and species. The spread of Leishmania species accompanied this pattern of distribution, showing clear signs of coevolution (KillickKendrick 1985). According to Galati (1995) the current species of the tribes Hertigiini and Phlebotomini occupy all the zoogeographical regions, suggesting that the an- 
cestor of these two tribes had already arisen during or even before the separation of the continents.

There are nearly 200 species of sand fly in the Palearctic and Ethiopian regions, compared with approximately 480 in the Neotropics. Only 14 species occur in the Nearctic and only five are precinctive for this region. Only four of the 23 Neotropical genera occur in North America and none are exclusive to the Nearctic, half of the 14 species belonging to the genus Micropygomyia. Most of these occur in the hottest, most humid areas of the region. Psathyromyia shannoni (Dyar) is the only species found in both these zoogeographical regions (Young \& Perkins 1984, Young \& Duncan 1994).

The temperate climate of the Nearctic is known to be unfavourable to phlebotomine development, particularly that of the immature stages. This fact reinforces the idea that the event that led to the appearance of the phlebotomine line occurred originally in the Tropics, from where a few species dispersed to the temperate regions, adapted and occupied vacant ecological niches, some populations undergoing speciation. It is to be expected that these species, whether autochthonous or not, would be younger than those present in the Tropics, and could even come to occupy new geographical areas, leading to geographical isolation of the first population and new processes of speciation. Young and Lawyer (1987) commented that the phlebotomines presently found in North America probably arose from South American stock. On the other hand modern-day phlebotomines could have arisen in the Nearctic during the arid phases of the Tertiary, their reduced presence being due to the constant climatic fluctuations that occurred in the Quaternary. These fluctuations could have caused many sand fly species to become extinct or displaced to the Tropics, where they may have adapted to the hotter, more humid conditions and undergone considerable adaptive radiation. The ecological niches abandoned during the glaciations have still not reoccupied by the remaining species. We consider the first hypothesis to be more likely, since the number of species is very limited and no genus is exclusive to the Nearctic.

According to Young and Lawyer (1987) the centre of distribution of the genus Lutzomyia (= subtribes Phlebotomiina and Psychodopygina) in the Neotropics is the forested lowlands to the east of the Andes, from where more than 40 species have been collected. One explanation for this would be the dry periods that occurred during the Pleistocene epoch and served to isolate conspecific populations, some of which became reproductively isolated and colonised more humid areas in the north and west. Nevertheless the idea that the Andes really are the place of origin of the present-day sand flies is supported by the presence of seven of the nine Neotropical species of the Hertigiini in the Andean Region, the two others being found in French Guiana, Costa Rica and Panama.

The occupation of new areas in the western Neotropics probably occurred during the long, constant climatic changes of the Pleistocene. These movements occurred not only for the phlebotomines, but also for several other animal groups of invertebrates and vertebrates, including those exploited by sand flies as sources of blood meals.
Sand fly dispersal would also account for the distribution of the Leishmania species transmitted by the insects. The new colonising populations adapted to new habitats, such as the Atlantic and Amazon Forests and subsequently underwent further speciation.

It is difficult to estimate the age of a given species, but we may suppose that the species that present a geographical distribution that extends over much of the Americas or either of the two zoogeographical regions should be very old. $P$. shannoni is found in both the Nearctic and Neotropical regions and is probably an ancient species. During the process of continental break-up Central America was formed by a chain of islands, North and South America remaining separate until the formation of the Isthmus of Panama during the Pliocene epoch of the Tertiary period. One may thus hypothesise that $P$. shannoni dispersed to the Nearctic after this had occurred, i.e., less than $5.1 \mathrm{myr}$ ago.

If the great glaciations really were responsible for the extinction of many species or their displacement to the Tropics, one might expect $P$. shannoni to have migrated to the Nearctic within the last 10,000 years, at the time of the last great glaciation. Even if we agree with some authors that $P$. shannoni is composed of more than one taxon or of genetically separated populations (Cárdenas et al. 2001, Mukhopadhyay et al. 2001), the phenotypic similarity observed between the putative species indicates that speciation was recent, insufficient time having elapsed to produce greater morphological diversity. Several neotropical sand flies are considered to represent cryptic species such as Nyssomyia intermedia s.l. which may have arisen as a result of recent allopatry ( $\sim 250,000$ years). The discovery in the Brazilian state of São Paulo of insects morphologically similar to $N$. intermedia s.s. but with DNA mitochondrial sequences apparently more characteristic of the related $N$. neivai indicates that separation of the two species was very recent, not yet complete and/or interbreeding occurred under particular conditions and at certain times of the year (Marcondes et al. 1997). Morphological variations in the number of tergal spots provided the first evidence that L. longipalpis was a species complex (Mangabeira 1969). Molecular studies with L. longipalpis s.l. from different regions of Brazil that bear one or two pairs of abdominal spots suggest that speciation was recent, occurring between 0.22 and 1.02 myr ago (Bauzer et al. 2002). Sufficient morphological diversity has occurred to create new species, as in Venezuelan populations recently described as L. pseudolongipalpis (Arrivillaga \& Feliciangeli 2001).

The absolute number of mutations in a given population is directly related to the total number of individuals in this same population. The greater the population size the higher the number of polymorphic loci, due to constant gene flow between individuals. Variations in the percentages of these loci occur in geographically isolated populations (Amorim 1994). Morphological variations do not always serve to maintain reproductive isolation. Hybridization may sometimes lead to speciation, when hybrids are maintained between two species. Another way in which new species could arise is by means of genetic or cytological changes in the individual, i.e., through chro- 
mosomal mutation or translocation leading to reproductive isolation. These forms of speciation are instantaneous, i.e., a new species may arise in a short space of time. Gradative speciation, i.e., that which occurs over time, may be sympatric if a biological barrier divides the members of a particular widely distributed population so that gene flow between them ceases or parapatric when selection favours different alleles in adjacent or allopatric populations. Thus geographical variations may lead to reproductive isolation.

Although phlebotomine species occur in sympatry in practically all habitats, hybridization has not been demonstrated in nature (Fryauff et al. 1991, Andrade Filho et al. 1999). Nevertheless it could provide sufficient genetic variation to permit adaptation to new habitats. Their alleles of the progeny could include some characteristics that arose through genetic recombination. Hybridization zones probably do exist between some species, principally those that are very similar morphologically and have wide geographical distributions.

The mechanisms of reproductive isolation among the phlebotomines probably follow the patterns for other Diptera. Thus the mechanisms of pre-copulatory reproductive isolation include seasonal isolation, as when two species are active sexually at different times of the year; ethological isolation, in which the potential sexual partners meet but the courtship behaviour of one or both species does not attract the other; chemical isolation, where the liberation of pheromones inhibits or fails to attract the closely related species; and mechanical isolation, where incompatibility of the copulatory organs impedes the exchange of genetic material. With regard to the post-zygotic mechanisms of reproductive isolation we can cite gametic mortality, in which sperm transfer occurs but the egg is not fertilized; zygotic mortality, where the egg is fertilized but the zygote does not survive; $h y$ brid inviability, where the F1 hybrid produced is not viable or has reduced viability; hybrid sterility, in which the F1 hybrid is sterile; and hybrid collapse, where the F1 is fertile but its progeny are inviable and do not survive to reproductive age. Post-copulatory mechanisms can not prevent the loss of time, energy and gametes that could be expended on a member of the same species.

\section{ACKNOWLEDGMENTS}

To Dr Rafael Gioia Martins-Neto (Sociedade Brasileira de Paleoartropodologia) Dr Beatriz Gomes Brazil (CPqRR) for criticisms and suggestions and Dr J Bruce Alexander for the English revision of the manuscript.

\section{REFERENCES}

Abonnenc E, Leger N 1976. Sur une classification rationelle des diptères Phlebotomidae. Cah Off Rech Sci Tech OutreMer (Ent Mèd)14: 69-78 .

Amorim DS 1994. Elementos Básicos de Sistemática Filogenética, Sociedade Brasileira de Entomologia, São Paulo, 314 pp.

Andrade Filho JD, Falcão AL, Brazil RP 1999. Hybridization between Lutzomyia lenti (Mangabeira) and Lutzomyia carmelinoi Ryan, Frahia, Laison \& Shaw (Diptera: Psychodidae). 3rd International Symposium on Phlebotomine Sandflies, Montpellier, France.
Ansorge J 1994. Tanyderidae and Psychodidae (Insecta:Diptera) from Lower Jurassic of Northeastern Germany. Paläon $Z$ 68: 199-210.

Arrivillaga JC, Feliciangeli MD 2001. Lutzomyia pseudolongipalpis: the first new species within the longipalpis (Diptera:Psychodidae:Phlebotominae) complex from Rinconada, Curarigua, Lara State, Venezuela. J Med Entomol 38: 783-790.

Azar D, Nel A, Solinace M, Paicheler JC, Bouchet F 1999. New genera and species of psychodid flies from Lower Cretaceous amber of Lebanon. Palaeontology 42: 11011136.

Bauzer LGSR, Souza NA, Ward RD, Kyriacou CP, Peixoto AA 2002. The period gene and genetic differentiation between three Brazilian populations of Lutzomyia longipalpis. Insect Mol Biol 11: in press

Brazil RP, Andrade Filho JD 2002. Description of Pyntomyia (Pifanomyia) falcaorum sp. n. (Diptera:Psychodidae: Phlebotominae), a fossil sand fly from Dominican amber. Mem Inst Oswaldo Cruz 97: 501-503.

Cárdenas E, Munstermann LE, Martínez O, Corredor, Ferro C 2001. Genetic variability among populations of Lutzomyia (Psathyromyia) shannoni (Dyar 1929) (Diptera: Psychodidae: Phlebotominae) in Colombia. Mem Inst Oswaldo Cruz 96: 189-196.

Chaniotis BN, Correa MA 1974 Comparative flying and biting activity of Panamenian phlebotomine sandflies in mature forest and adjacent open space. J Med Entomol 8: 369-375.

Duckhouse DA 1965. Psychodidae (Diptera:Nematocera) of southern Australia, subfamilies Bruchomyiinae and Trichomyiinae. Trans R Entomol Soc Lond 117: 329-343.

Duckhouse DA 1972. Psychodidae (Diptera:Nematocera) of South Chile, subfamilies Sycoracinae and Trichomyiinae. Trans $R$ Soc Entomol Lond 124: 231-268.

Duckhouse DA 2000. Redescription and re-evaluation of the Burmese amber psychodid Eophlebotomus connectens Cockerell and its phylogenetic position (Diptera: Psychodidae). Systematic Entomol 25: 503-509

Fairchild GB 1951. Some nomenclaturial notes on Psychodidae (Diptera). Bull Brooklyn Entomol Soc 46: 10-18.

Fraser NC, Grimaldi DA, Olsen PE, Axsmith B 1996. A triassic Lagerstätte from Eastern North America. Nature 380: 615619.

Fryauff DJ, Hanafi H 1991. Demonstration of hybridization between Phlebotomus papatasi (Scopoli) and Phlebotomus bergeroti Parrot. Parassitologia 33 (Suppl. 1): 237-243.

Galati EAB 1995. Phylogenetic systematics of Phlebotominae (Diptera, Psychodidae) with emphasis on American groups. Bol Direc Malariol y San Amb 35 (Supl. 1): 133-142.

Haenni JP 2001. Fossil Diptera in Baltic amber: the collection of the Muséum d'Histoire Naturelle Neuchatel. International Congress on Paleoentomology, p. 23-24.

Harland WB, Cox AV, Llewellyn PG, Pickton CAG,Smith AG, Walters R 1982. A Geologic Time Scale, Cambridge University Press, Cambridge, UK.

Hennig W 1972 Insektenfossilien aus der unteren Kreide. IV. Psychodidae (Phlebotominae), mit einer kritischen Übersicht über das phylogenetische System der Familie und die bisher beschriebenen Fossilien (Diptera). Stuttgarter B Naturkunde (Serie A) 241: 1-69.

Kerr SF 2000. Paleartic origin of Leishmania. Mem Inst Oswaldo Cruz 95: 75-80.

Kerr SF, Merkelz R, MacKinnon C 2000. Futher support for a Paleartic origin of Leishmania. Mem Inst Oswaldo Cruz 95: 579-581.

Killick-Kendrick R 1985. Some epidemiological consequenses of the evolutionnary fit between leishmaniae and their 
phlebotomine vectors. Bull Soc Pathol Exot 78: 747-755.

Lewis DJ 1982 A taxonomic review of the genus Phlebotomus (Diptera:Psychodidae). Bull Brit Mus (Natural History) 45: 121-129.

Lewis DJ, Young DG, Fairchild GB, Minter DM 1977 Proposals for a stable classification of the phlebotomine sandflies (Diptera:Psychodidae). Syst Entomol 2: 319-332.

Mangabeira O 1969. Sobre a sistematica e biologia dos flebótomos do Ceará. Rev Bras Mal D Trop 21: 3-26.

Marcondes CB, Day JD, Ready PD 1997. Introgression between Lutzomyia intermedia and both $\mathrm{Lu}$. neivai and $\mathrm{Lu}$. whitmania, and their roles as vectors of Leishmania braziliensis. Trans R Soc Trop Med Hyg 91: 725-726.

Meunier F 1905. Monographie des psychodidae de l'Ambre de la Baltique. Annls Mus Natn Hungarici 3: 235-253.

Meunier F 1906. Um nouveau genre de Psychodidae et une nouvelle espéce Dactylolabis (Tipulidae) de l'Ambre de la Baltique. Naturalists 28: 103-104

Morales CJ, Pimentel FZ 2001. Diptera order in the amber of Chiapas, Mexico. 2nd International Congress on Paleoentomology p.47-48.

Morrison AC 1993. Dispersal of the sand fly Lutzomyia longipalpis (Diptera:Psychodidae) at an endemic focus of visceral leishmaniasis in Colombia. J Med Entomol 30: 427-435.

Mukhopadhyay J, Ghosh K, Ferro C, Mustermann LE 2001.
Distribution of phlebotomine sand fly genotypes ( $\mathrm{Lu}$ tzomyia shannon, Diptera: Psychodidae) across a highly heterogeneous landscape. J Med Entomol 38: 260-267.

Noyes HÂ, Morrison DA, Chance ML, Ellis JT 2000. Evidence for a neotropical origin of Leishmania. Mem Inst Oswaldo Cruz 95: 575-578.

Quate LW 1963. Fossil Psychodidae in Mexican amber, Part 2 Diptera: Insecta. J Paleontol 37: 110-118.

Rasnitsyn AP, Ross AJ 2000 A preliminary list of arthropods families present in the Burmese Amber collection at Natural History Museum, London. Bull Nat Hist Mus Lond (Geol) 56: 21-24.

Stuckenberg BR 1975. New fossil species of Phlebotomus and Haematopoda in Baltic amber (Diptera:Psychodidae, Tabanidae). Ann Natal Mus 22: 455-464.

Young DG, Duncan MA 1994. Guide to the identification and geographic distribution of Lutzomyia sand flies in Mexico, The West Indies, Central and South America (Diptera: Psychodidae). Mem Amer Ent Inst 54: 1-881.

Young DG, Lawyer PG 1987. New World vectors of the leishmaniases. In KF Harris, Current Topics in Vector Research, Springer-Verlag, New York, p. 29-37.

Young DG, Perkins PV 1984. Phlebotomine sand flies of North America (Diptera:Psychodidae). Mosq News 44: 263-304.

Williams P 1993. Relationships of phlebotomone sand flies (Diptera). Mem Ins Oswaldo Cruz 88: 177-183 